\title{
A IMPORTÂNCIA DO ENFERMEI- RO NA CONCIENTIZAÇÃO E PREVENÇAO DO HPV
}

DOI: 10.22289/2446-922X.V5N1A8

\author{
Lara Cristina Siqueira Fernandes ${ }^{1}$ \\ Renata Ferreira dos Santos Oliveira
}

\section{RESUMO}

As DST's (doenças sexualmente transmissíveis) são doenças pesquisadas entre os cientistas de todo o mundo, e com o avançar do conhecimento científico e tecnológico, a população tem maior acesso às informações. Atualmente, preocupa-se a precocidade da vida sexual, a falta de prevenção e o não uso de métodos contraceptivos. Isso leva ao aumento do número de DST's, que, em grande maioria, compromete o funcionamento do corpo humano, como é o caso do Papiloma Vírus Humano (HPV). Assim, este trabalho aborda como os HPV são classificados em tipos de baixo e de alto risco de câncer, bem como a forma de transmissão do HPV: pelo contato direto com pele, mucosas infectadas por meio de relação sexual e da mãe para filho no momento do parto. A transmissão ocorre por contato direto com a pele infectada, sendo, então, altamente contagioso, e contamina-se com uma única exposição. O vírus começa sua replicação primária, acometendo este epitélio escamoso, com centenas de partículas virais maturas. Após penetração no citoplasma, a cápsula é total ou parcialmente removida e o genoma viral é exposto, espalhando-se de célula para célula. O diagnóstico realizado através da citologia oncótica é eficaz, de baixo custo e bastante acessível para a população, porém, sua detecção através da técnica de PCR é mais rápida, mais precisa, entretanto tem um custo um pouco mais elevado. Este trabalho de conclusão de curso foi realizado através da revisão literária exploratória. Foram utilizados livros, artigos científicos, dissertações, monografias, teses, manuais que foram adquiridos por meio de aquisição própria e empréstimo, busca em bases de dados da internet, tais como Scielo, Bireme e ainda busca em sites de instituições de ensino superior, tendo por finalidade explicar a importância do diagnóstico pela técnica de PCR do Papiloma Vírus Humano - HPV, dando ênfase à detecção molecular do HPV pela técnica de PCR. Assim, como resultado do estudo comparativo de literaturas afins entre outras técnicas de detecção, como a captura hibrida e a hibridização in situ, foi possível compreender que a técnica de PCR possui maior sensibilidade do que as demais apresentadas.

Palavras Chaves: Papilomavirus; PCR; Tratamento.

\footnotetext{
${ }^{1}$ Endereço eletrônico de contato: laracristinafernandes@yahoo.com.br

Recebido em 23/10/2018. Aprovado pelo conselho editorial para publicação em 16/11/2018.
}

Rev. Psicol Saúde e Debate. Jul., 2019:5(1):80-109. 


\section{ABSTRACT}

STDs are commonly known diseases among scientists around the world, and with the advancement of scientific and technological knowledge, the population has greater access to information. Currently, there is concern about the precocity of the sexual life, lack of prevention and the non-use of contraceptive methods. As a result, there is an increase in the number of STDs, which, in large part, compromise the functioning of the human body, such as human papillomavirus (HPV). HPVs are classified into low-risk and high-risk types of cancer. HPV is transmitted by direct contact with infected skin or mucous membranes through intercourse. It can also be transmitted from mother to child at delivery. Transmission occurs by direct contact with infected skin. HPV is highly contagious and can be contaminated with a single exposure. The virus begins its primary replication, affecting this squamous epithelium, with hundreds of mature viral particles. After penetration into the cytoplasm, the capsule is totally or partially removed and the viral genome is exposed, spreading from cell to cell. The diagnosis made by the oncotic cytology is effective, low cost and very accessible for the population, but the detection through PCR is faster, more accurate, but has a slightly higher cost. This work of course completion aims to explain the importance of the diagnosis by PCR Human Papillomavirus - HPV. This work aims to emphasize the molecular detection of HPV by the PCR technique, making a comparative study among other detection techniques such as hybrid capture and in situ hybridization. At the end of this literature review, it is possible to understand that the PCR technique has greater sensitivity than the others presented.

Key Words: Papillomavirus; PCR; Treatment.

\section{INTRODUÇÃO}

O Papiloma Vírus Humano (HPV) é o vírus que causa, com frequência, verrugas em diferentes partes do corpo, como mãos e pés, e, principalmente, nos genitais. Mais de uma centena de sorotipos virais que infectam a espécie humana já foram identificados, e, entre eles, 40 são responsáveis por infecções anogenitais.

Nas últimas décadas, o interesse em diversos aspectos envolvidos na infecção pelo HPV tem aumentado, não apenas devido à frequência elevada de sua ocorrência (mais de cinco milhões de infecções anuais apenas nos Estados Unidos da América), segundo fonte Rama (2006), mas, principalmente, porque estudos comprovam que alguns tipos de HPV causam câncer.

A infecção pelo HPV é a mais comum infecção sexualmente transmissível (IST) entre os jovens sexualmente ativos e um dos principais problemas de saúde pública em diversos países. Em muitos casos, a infecção é transiente e vencida pelo íntegro sistema imunológico dos pacientes (Santos, 2013).

Em estudos realizados por Palefsky (2008), entre mulheres com grave comprometimento imunológico, resultante da coinfecção pelo vírus da imunodeficiência adquirida (HIV), $70 \%$ 
apresentavam lesões HPV - negativas e portadoras da infecção pelo HPV. A associação causal entre infecções persistente por HPV e câncer cervical é semelhante à existente entre tabagismo e câncer do pulmão. Estudos epidemiológicos têm comprovado que a infecção cervical por tipos oncogênicos de HPV eleva em trinta vezes o risco para câncer de colo do útero, nível similar ou maior do que aquele para câncer de pulmão entre fumantes.

De acordo com Zhang et al (2004), ao que parece, ter o HPV é "condição" para o desenvolvimento da neoplasia cervical, porém esta infecção, sozinha, não é suficiente para desenvolver o tumor na ausência de cofatores como tabagismo e déficit imunológico. A estratégia primária de prevenção das ISTs, - como diagnósticos e tratamento dos portadores e de seus parceiros sexuais - tem resultado limitado nos casos de infecção por HPV, pela ocorrência de portadores assintomáticos e pela inexistência de terapia que leve à cura da infecção. Deste modo, os recursos disponíveis, atualmente, usados no tratamento das verrugas e das infecções cervicais pelo HPV, em presença ou não de lesões precursoras do câncer, erradicam o tecido anormal, mas não eliminam inteiramente a infecção.

Até que a vacina se torne uma realidade disponível, a informação e a prevenção da infecção pelo HPV, aliadas aos métodos de diagnósticos e tratamento das lesões precursoras, são os mecanismos por meio dos quais se podem reduzir as taxas de câncer cervical. Na última década, a maior descoberta sobre a etiologia da carcinogênese na espécie humana foi o reconhecimento de que o carcinoma cervical é uma rara consequência da infecção por certos tipos de HPV de alto risco. Tal infecção ocorre frequentemente durante a juventude e é dependente do comportamento (Silva, 2007).

Para Varela (2009), os números de casos de neoplasias do colo do útero causadas pelo papiloma vírus humano diminuíram consideravelmente, pois se tem descoberto a doença com tempo hábil para seu tratamento e cura. Sendo assim, pode-se afirmar que conhecer a ação deste vírus no organismo e as doenças que é capaz de causar neoplasias, é de suma importância, uma vez que se pode, assim, sanar deficiências, tanto no tratamento oferecido para uma possível cura, como nas divulgações e campanhas para que se realizem periodicamente os exames preventivos, pois apenas com esses pode se ter a certeza de anormalidades.

A infecção pelo HPV é endêmica entre os indivíduos sexualmente ativos. Segundo, Alberto Chebabo, infectologista do Hospital Universitário Clementino Fraga Filho, da UFRJ, as infecções pelo Papiloma Vírus Humano vêm aumentando significativamente. O diagnóstico da infecção por HPV é obtido pela detecção dos seus efeitos morfológicos sobre a citologia e histopatologia, ou do seu ácido desoxirribonucléico (DNA). Neste aumento de índice, inscrevese a importância do trabalho e a necessidade de a ciência discutir e colocar em pauta o tema (Rama, 2006). 


\section{METODOLOGIA}

A pesquisa refere-se e a um estudo de revisão sistemática de literatura, portanto este trabalho foi desenvolvido através de um estudo comparativo de literaturas sobre a importância do diagnóstico pela técnica de PCR do Papiloma Vírus Humano. Foram utilizados livros, artigos científicos, dissertações, monografias, teses, manuais que foram adquiridos por meio de aquisição própria e empréstimo, busca em bases de dados da internet, tais como Scielo, Bireme, BVS e ainda busca em sites de instituições de ensino superior e revistas cientificas entre outros, preferencialmente entre os anos de 2012 a2017. Foram selecionados 32 artigos dos quais utilizou-se 18, por estarem em conformidade com o tema proposto. Para análise dos dados, seguiu-se a lógica apresentada na descrição dos resultados dos quais foram: atribuições do enfermeiro de PSF, a baixa adesão a vacina contra o HPV, após a análise da literatura foi feita a discussão das ideias e pontos de vistas obtidos, realizadas as devidas observações, iniciou-se a pesquisa, dirigindo o artigo com ênfase à detecção molecular do HPV pela técnica de PCR, por meio de técnicas de detecção, como a captura hibrida e a hibridização in situ. Ao final desta revisão narrativa conceitual, de cunho bibliográfico, foi possível compreender, confirmando a hipótese inicial, que a técnica de PCR possui maior sensibilidade do que as demais apresentadas (Sacramento, 2011).

\section{REFERENCIAL TEÓRICO}

\subsection{PAPILOMA VÍRUS HUMANO (HPV)}

No final do século XX, com as mudanças no comportamento sexual em todo o mundo, surgiram novas doenças sexualmente transmissíveis, como a Síndrome de Imunodeficiência Adquirida (AIDS) e outras de importância até então secundária que, pelo aumento da incidência, despertaram o interesse em seu estudo, como a condilomatose genital (Albring et al., 2006)

Tem-se conhecimento de verrugas genitais desde a época greco-romana, período em que atribuíam a transmissão da doença por contato homossexual. $O$ interesse pelo estudo do HPV aumentou na década de 80 , em proporção similar à incidência das alterações por ele induzidas nas mulheres. Comprovou-se que mulheres de parceiros promíscuos, ou que mulheres de parceiros, cuja esposa anterior tivesse falecido de câncer do colo uterino, pertenciam ao grupo de grande risco para infecção por HPV e também para o câncer do colo uterino. As pequenas elevações e lesões foram descritas como condilomas, semelhantes à couve-flor (Silva et al., 2007).

Rev. Psicol Saúde e Debate. Jul., 2019:5(1):80-109. 
A partir de 1976, através da caracterização cito-histológica da infecção cervical, permitiuse acumular grande volume de conhecimento sobre a estrutura e a organização genética do HPV, os métodos de diagnóstico e de detecção virótica, o tratamento e a relação com o câncer (Rama, 2006).

O conhecimento das lesões subclínicas cervicais e vaginais originou a investigação de lesões semelhantes em outras partes da genitália feminina, na qual se utilizou o colposcópio para esta finalidade, possibilitando o surgimento da colposcopia, vulvoscopia e anuscopia, sendo detectadas respectivamente as lesões subclínicas no colo do útero, na vulva e no ânus (Silva et al., 2007).

Segundo fonte anteriormente citada, o HPV tem formato isocaédrico, mede aproximadamente $55 \mathrm{~nm}$ e possui 72 capsômeros, além do genoma com dupla hélice de DNA circular. É destituído de envelope e, na atualidade, existem mais de 200 sorotipos descritos, cada tipo viral sendo definido por um genoma que difere em mais de $10 \%$ de qualquer outro na sequência de nucleotídeos de seus três genes. Os vírus, em sua forma epissomal, estão presentes nos tumores benigno e, quando integrados aos cromossomos das células hospedeiras, são encontrados nas neoplasias malignas. O HPV é o vírus responsável, com frequência, por verrugas em diferentes partes do corpo, como mãos, pés, e, principalmente, nos genitais (Rama, 2006).

Nas últimas décadas, o interesse por diversos aspectos envolvidos na infecção pelo HPV tem aumentado, não apenas devido à frequência elevada de sua ocorrência, mas sim e, principalmente, porquanto estudos comprovam que alguns tipos de HPV estão relacionados ao surgimento de câncer no colo do útero. A transformação maligna resulta da ação sinérgica entre HPV's, oncogenes e de cofatores, que, em nível de colo uterino, são: infecção persistente por HPV de alto risco, tabagismo, imunossupressão, precocidade sexual, múltiplos parceiros ou único promíscuo e multiparidade. Interferem ainda neste processo, logicamente, as condições socioeconômicas e a predisposição genética da paciente (Rama, 2006).

Em vários estudos epidemiológicos, tem sido relatado que o HPV é o principal fator de risco para o câncer cervical. Outros fatores de risco também podem estar associados ao desenvolvimento deste tipo de câncer, como o início precoce da atividade sexual, multiparidade, curto intervalo entre gestações, elevado número de parceiros sexuais, promiscuidade do parceiro sexual, desnutrição em função da alimentação insuficiente e inadequada, hábitos de higiene e tabagismo (Novaes, 2008).

De acordo com Rama (2006, p. 33)

O HPV é classificado conforme a espécie de hospedeiro natural e sub classificado em tipos de acordo com as sequências de nucleotídeos do DNA. Atualmente, são conhecidos 
mais de 90 tipos de HPV com base na homologia do seu DNA, sendo que aproximadamente 30 possuem tropismo pelo trato anogenital e, esses são divididos em alto e baixo risco para o desenvolvimento do câncer, conforme o seu potencial oncogênico.

Nesta linha de raciocínio, a genômica de todos os HPVs é semelhante, pois o genoma viral divide-se em três regiões: a região "early" (precoce), que contém os genes $E_{1}, E_{2}, E_{4}, E_{5}, E_{6}$ e $E_{7}$, os quais se tornam necessários à replicação viral com propriedades de transformação oncogênica; região "late" (tardia), com os genes $L_{1}$ e $L_{2}$, que possuem códigos de formação de proteínas do capsídeo viral; a região regulatória (LCR), a qual contém a origem da replicação e o controle dos elementos para transcrição e replicação (Palefsky, 2008).

\subsection{BIOLOGIA MOLECULAR DO VÍRUS}

De acordo com Castro (2010), O DNA viral dentro da célula hospedeira pode assumir duas formas: epissômica e integrada. Na forma epissomal, o DNA viral permanece circular no núcleo da célula hospedeira e não se integra ao seu DNA. Esta forma é encontrada em verrugas genitais e ferimentos leves. Para a integração do genoma circular no DNA da célula hospedeira, esse deve ser linearizado pela decomposição do DNA viral entre as regiões E1 e L1, o que resulta na ruptura ou perda do gene E2, sendo encontrado em lesões mais graves, como carcinoma "in situ" e invasivo. Após a integração de HPV's de alto risco no genoma celular, eles começam a codificar as oncoproteínas $\mathrm{E} 6$ e $\mathrm{E} 7$, as quais promovem o processo maligno. A célula hospedeira possui os genes supressores de tumor RB e TP. O gene RB é o principal regulador do ciclo celular e o gene TP é chamado de "guardião do genoma" porque é projetado para controlar se todos os genes estão intactos. 


\section{ThREE-Dimensional MOdel of Human PAPILlomavirus}

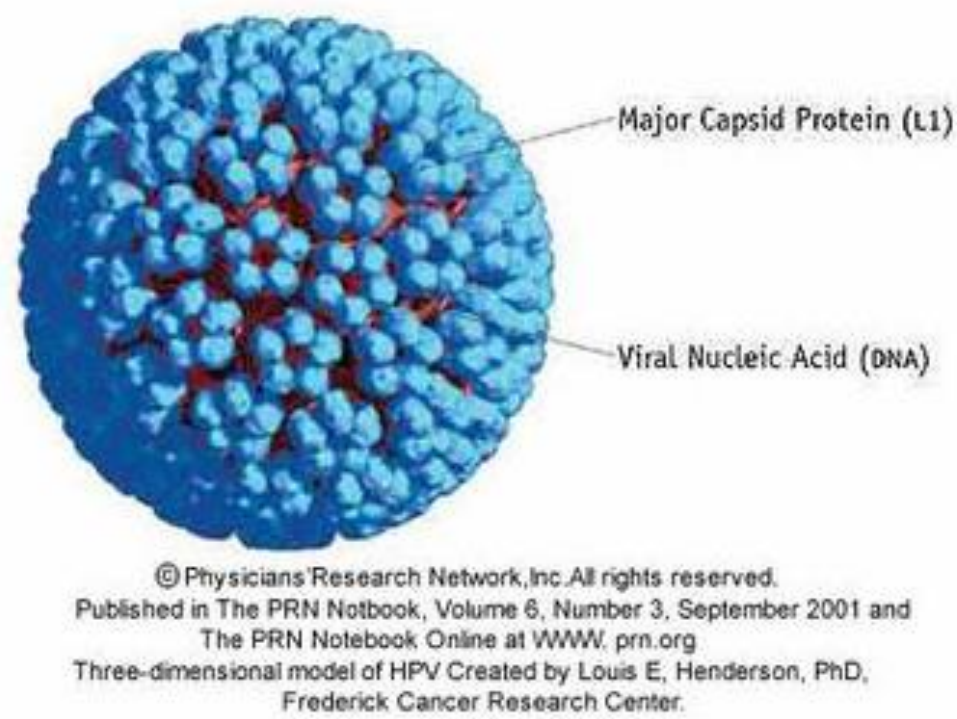

Figura 1. Imagem tridimensional do vírus HPV - L1 proteína de capsídeos maiores (proteína estrutural do vírus) - DNA- Ácido Nucleio Viral

Fonte: Graça(2018)

\subsection{CICLO BIOLÓGICO DO víRUS}

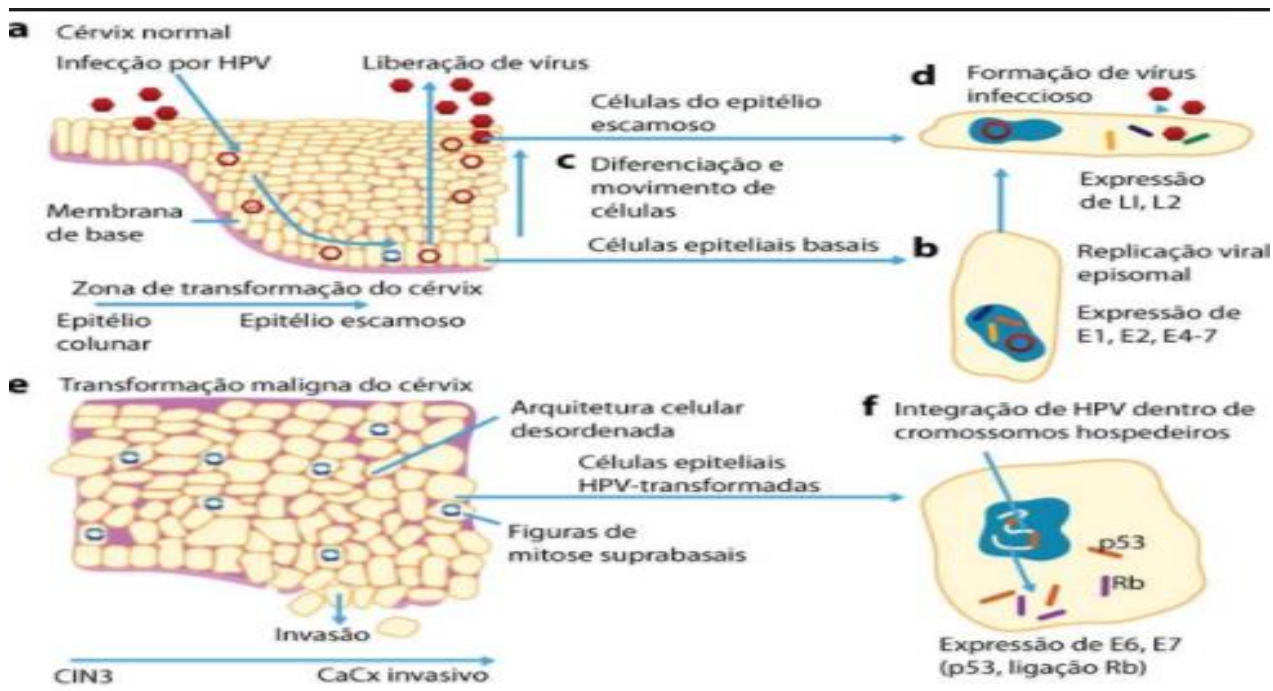

Figura 2. Ciclo Biológico do Vírus

Fonte: Paiva (2018)

A figura 1,traz o ciclo biológico do vírus HPV.

a) Novos vírus são liberados assim que as células se replicam em direção à superfície do epitélio;

(c) O DNA viral se integra ao DNA da célula epitelial hospedeira;

(f) O vírus depende da síntese das proteínas L e proteínas E. As proteínas E6 e E7 estão particularmente ligadas ao aparecimento de células cancerosas (d, b e f).

Rev. Psicol Saúde e Debate. Jul., 2019:5(1):80-109. 
Quando ocorre a malignização do tecido do colo do útero, é visível uma arquitetura desordenada do tecido e pode acontecer a invasão de camadas mais profundas, agravando o quadro (e).

Discorrendo sobre a figura acima, lembra-se que os HPV's, em sua forma epissomal, estão presentes em tumores benignos, e, quando integrados aos cromossomos das células hospedeiras, são encontrados nas neoplasias malignas. São descritas três regiões genômicas do DNA do HPV. Uma região de codificação precoce E (early coding region); uma região de codificação tardia $L$ (late coding), ambas separadas por uma região não codificante (long control region). Estas proteínas virais interferem no mecanismo de interação e de instalação na célula hospedeira, resultando no efeito citopático e na formação de neoplasias (Rama, 2006). A despeito disso, registra-se que a imunossupressão resultante da infecção pelo HIV oferece condições favoráveis à persistência do HPV anogenital. O tempo de evolução entre as lesões precursoras de NIC I, NIC II, NIC III e Ca in situ, até o carcinoma invasor, que, em mulheres com imunidade normal, pode levar de 10 a 15 anos, nas imunocomprometidas, mostra progressão assustadoramente mais rápida (Graça, 2018). Em geral, não se pode deixar de enfatizar, que segundo dados de Sacramento (2011), nos casos de NIC I, associados ao HPV, há persistência em $30 \%$ e regressão em $60 \%$ dos casos. Em portadoras de NIC II, constata-se igual percentual de persistência e de progressão, em torno de $40 \%$ das pacientes, enquanto em portadoras de NIC III, a regressão ocorre apenas em $30 \%$, sendo, portanto, alta a chance de surgimento do câncer invasor. Sem dúvidas, o tipo viral e a carga viral do HPV, além da persistência da infecção, representam fatores relevantes no processo. O HPV infecta a pele e as membranas mucosas, onde iniciam o ciclo infeccioso à medida que penetram nas camadas mais profundas do tecido epitelial do colo do útero, particularmente na junção escamocolunar ou nas regiões genitálias. Após um período de incubação, variante de meses a anos, as manifestações clínicas como lesões (verrugas) no câncer cervical (Pereyra \& Parellada, 2003; Burd, 2003).

O reconhecimento de que a infecção pelo HPV no trato genital pode estar associada a lesões pré-cancerosas é relativamente recente. Algumas anormalidades planas do epitélio do colo do útero, até então consideradas como lesões intraepiteliais neoplásicas, apresentavam a mesma aparência citológica das lesões verrucosas. Este aspecto foi a presença de células conhecidas como colócitos (Tacla, 2018).

A progressão maligna é o resultado da integração do HPV e da expressão de alguns genes, nos quais há uma mudança na relação entre o hospedeiro e o vírus. Este processo é mostrado como um epitélio normal, passando por lesões de baixo grau, até lesões de alto grau antes de se tornar um câncer invasivo. Nesta progressão, o vírus, previamente na forma epissomal (circular), passa para a forma linear e é incorporado ao DNA da célula epitelial do 
hospedeiro (HSIL) caracterizado por um crescimento celular anormal e diferenciação que se origina na replicação de células de a camada basal do epitélio original (Silva et al., 2007).

Este fenômeno produz alterações morfológicas em todas as camadas do epitélio e células menores que as observadas na lesão intraepitelial escamosa de baixo grau (Zhang et al., 2004). Em relação ao início da atividade sexual, demonstrou-se em vários estudos que ela ocorre antes dos 16 anos, dobrando o risco de desenvolvimento de câncer em comparação àqueles que começam após os 20 anos de idade.

O número de parceiros sexuais durante a vida e a promiscuidade do parceiro sexual são importantes fatores de risco para a infecção genital pelo HPV. Tem sido relatado que os parceiros sexuais de mulheres com câncer de colo do útero tiveram várias infecções genitais, incluindo verrugas e até câncer de pênis (Burd, 2003).

A alta paridade é um fator constante para o câncer cervical em mulheres com DNA do HPV. O fator de risco é dobrado naquelas que tiveram 4 filhos, comparados com as que tiveram 1 ou nenhum. Com relação aos contraceptivos orais, o uso prolongado aumenta o risco de desenvolver carcinoma cervical. Estas pílulas contêm hormônios como dexametasona, progesterona e estrogênio, que aumentam a expressão genética do HPV (Burd, 2003).

A infecção pelo HPV, tem-se que se falar, é a mais comum infecção sexualmente transmissível entre jovens sexualmente ativos e um dos principais problemas de saúde pública em diversos países. A associação causal entre infecção persistente por HPV e câncer cervical é semelhante à existente entre tabagismo e câncer do pulmão. Estudos epidemiológicos têm comprovado que a infecção cervical por tipos oncogênicos de HPV eleva em 30 vezes o risco para câncer do colo do útero, nível similar ou maior do que aquele para o câncer do pulmão entre os fumantes (Silva et al., 2007).

Ao que parece, ter o HPV é "condição" para o desenvolvimento da neoplasia cervical, porém esta infecção sozinha não é "suficiente" para desenvolver o tumor na ausência de cofatores como tabagismo e déficit imunológico (Tacla, 2008).

De acordo com Graça (2018), o reconhecimento de que a neoplasia cervical é HPV induzida, tem importância em políticas de Saúde Pública. Estratégias primárias de prevenção das ISTs, como o diagnóstico e o tratamento dos portadores e de seus parceiros sexuais, têm resultado limitado nos casos de infecção por HPV, devido à grande ocorrência de portadores assintomáticos e pela inexistência de terapia que leve à cura da infecção.

Os recursos disponíveis atualmente, usados no tratamento das verrugas e de infecções cervicais pelo HPV, na presença ou não de lesões precursoras do câncer, erradicam o tecido anormal, mas não eliminam inteiramente a infecção (Tacla, 2008).

A informação e a prevenção da infecção pelo HPV, aliadas aos métodos de diagnóstico e tratamento das lesões precursoras, são os mecanismos por meio dos quais se podem reduzir 
as taxas de câncer cervical. Na última década, a maior descoberta sobre a etiologia da carcinogênese na espécie humana foi o reconhecimento da infecção por certos tipos de HPV de alto risco. Tal infecção ocorre frequentemente durante a juventude e é dependente do comportamento sexual (Varella, 2009).

Apesar de estratégias eficazes para sua prevenção, o câncer do colo do útero continua sendo um grave problema de saúde pública, especialmente em países em desenvolvimento (Campisi et al., 2015).

\subsection{EPIDEMIOLOGIA}

No Brasil, o câncer cervical representa o terceiro mais frequente entre as mulheres, sendo que mais de $70 \%$ dos diagnósticos ocorrem em fases avançadas da doença. As mulheres que apresentam infecções persistentes por HPV, constituem o verdadeiro grupo de risco para o desenvolvimento do câncer cervical, com um risco relativo de 100 a 300 vezes em relação àquelas em que a infecção não foi persistente (Novaes, 2008).

Estudos de base populacional sugerem que a prevalência da infecção genital por HPV segue uma curva bimodal, ou seja, de maior predomínio entre as jovens, declínio nas mulheres com mais de30 anos e novo pico ao redor dos 55 anos ou mais, de intensidade e grandeza semelhante à observada nas jovens. Estudos também têm observado o aumento desta infecção na perimenopausa e após a menopausa (Paiva, 2018).

De acordo com Ginsburg (2016), as características anatômicas dos órgãos sexuais masculinos permitem que as lesões sejam mais facilmente reconhecíveis; nas mulheres, porém, elas podem espalhar-se por todo o trato genital e alcançar o colo do útero, uma vez que, na maior parte dos casos, só são diagnosticáveis por exames especializados. Sendo assim, são inúmeros os fatores de risco para a incidência de câncer do colo do útero: baixas condições socioeconômicas, atividade sexual precoce, múltiplos parceiros sexuais, fumo, outras doenças sexualmente transmitidas tais como herpes e clamídia e falta de higiene. A neoplasia do colo do útero, juntamente com o câncer de mama, faz parte dos maiores medos das mulheres, o HPV acaba agindo como um precursor desta doença. No mundo, o câncer do colo do útero é a segunda malignidade mais comum entre as mulheres. No Brasil, representa a terceira malignidade mais comum e no estado do Rio Grande do Sul (RS) é a quarta principal causa de morte entre as mulheres, representando $10 \%$ de todas as malignidades femininas. Esta doença pode ser detectada precocemente pelo rastreamento citológico em programas de saúde pública. (International Agency for Research on Cancer [larc], 2005).

Apesar de estratégias eficazes para sua prevenção, o câncer do colo do útero continua sendo um grave problema de saúde pública, especialmente nos países em desenvolvimento. As

Rev. Psicol Saúde e Debate. Jul., 2019:5(1):80-109. 
mais altas taxas de incidência ocorrem na América Central (44,44/100.000), em algumas partes da Ásia (43,40/100.000) e no sul da África (40,44/100.000). Na América Latina, a incidência também é alta, variando de $31,79 / 100.000$ no norte, e 27,69/100.000 no sul do continente (larc, 2005).

No Brasil, o câncer cervical representa o terceiro mais frequente entre as mulheres, sendo que mais de $70 \%$ dos diagnósticos ocorrem em fases avançadas da doença. A relação entre o câncer cervical e a infecção por HPV já está bem estabelecida, pois se consegue detectar o DNA do HPV em 92,9\% a 99,7\% dos espécimes de câncer cervical invasivo. Tal fato fez com que a Internacional Agency for Research on Cancer classificasse os tipos de HPV 16 e 18 como carcinogênicos e os tipos 31 e 33 como provavelmente carcinogênicos (larc, 2005).

Recentemente, novos tipos foram incluídos aos carcinogênicos, como os mucosotrópicos ano-genitais: $31,33,35,39,45,51,52,56,58,59$ e 66 , os que infectam a pele, 5 e 8 e ainda, os tipos virais 6 e 11 foram classificados como possivelmente carcinogênicos (larc, 2005).

Para Ferraz, et al (2012), estimativas da OMS indicam que 190 milhões de mulheres no mundo são portadoras do vírus, sendo $32 \%$ infectadas pelos tipos 16 e 18. Em relação ao câncer do colo do útero, estudos apontam que 265 mil mulheres morrem devido à doença em todo o mundo, anualmente.

No Brasil, o Instituto Nacional do Câncer estima 16 mil novos casos. Porém, a infecção pelos tipos virais de alto risco é necessária, mas não é suficiente para o desenvolvimento do câncer cervical. Habitualmente, a infecção por HPV é um fenômeno transitório; sendo que em 90\% dos casos, ela não é mais detectada após 36 meses; entretanto, uma pequena fração das mulheres, provavelmente por falha de mecanismos imunológicos, apresenta persistência da infecção, que pode provocar alterações atípicas no epitélio cervical e evoluir para transformação maligna. Então, as mulheres que apresentam infecção persistente por HPV constituem o verdadeiro grupo de risco para o desenvolvimento do câncer cervical, com um risco relativo de 100 a 300 vezes em relação àquelas em que a infecção não foi persistente (Fonseca e Castro, 2016).

Cerca de 40 tipos do HPV, conforme dados de Campisiet al. (2015), acometem o trato genital pelo contato sexual, caracterizando esta infecção como a doença sexualmente transmissível atualmente mais frequente. Entre os fatores de risco para a infecção por HPV, o mais consistente é o número de parceiros sexuais durante a vida, também figuram os hábitos dos parceiros sexuais, a idade do parceiro sexual em relação à da mulher, com o dobro do risco a cada aumento de 1,5 ano na idade do parceiro masculino. O papiloma vírus humano é destituído de envelope e, na atualidade, existe mais de 200 sorotipos descritos, cada tipo viral sendo definido por genoma que difere em mais de $10 \%$ de qualquer outro na sequência de nucleotídeos de seus três genes. 
Pesquisas de Varela (2009) têm demonstrado que grandes números de vertebrados podem ser infectados pelo HPV, no entanto, os tipos virais são específicos da espécie parasitada. $\mathrm{Na}$ espécie humana, os HPVs têm distribuição universal, podem infectar pele e mucosas, induzir a formação de tumores benignos e malignos, representando, atualmente, a infecção sexualmente transmissível mais prevalente. A maioria dos estudos de prevalência da infecção pelo HPV relaciona-se com a presença do vírus na região anogenital, muito embora, em diversas regiões compostas por tecido cutâneo mucoso, o vírus já tenha sido detectado com frequência elevada, como, por exemplo, na orafaringe. O HPV tem difícil controle, porque implica mudança comportamental, mas também devido à fácil contagiosidade, em decorrência de ser o vírus nãocapsulado. A infecção clínica pelo HPV, caracteriza-se pela presença de verrugas, presente em $1 \%$ dos portadores do vírus, com aproximadamente 1,4 milhões de indivíduos. Ainda de acordo com mesmo modelo de prevalência estimada de HPV, 4\% da população mundial são portadores de HPV subclínico, diagnosticável pelo encontro de coilocitose, em exames cito-histopatológicos (Silveira et al., 2011).

O período de incubação varia de três semanas a oito meses, quando surgem as lesões clínicas (verrugas). Em geral, três meses depois inicia-se a resposta imune, que pode conter a infecção (regressão) ou permitir a fase de expressão ativa. A expressão viral ativa poderá reduzir a formação de fatores que retardam a resposta imune a partir da atividade de oncoproteínas (Sacramento, 2011).

De acordo com Castro (2010), na fase tardia da infecção, em geral, nove meses após o surgimento das verrugas, os pacientes poderão permanecer em remissão, sendo portadores assintomáticos e, portanto, transmissores do vírus; ou poderão expressar a doença ativa.

As principais vias de transmissão do HPV são sexuais e maternas-fetais. A via sexual é a mais efetiva e o vírus penetra na pele e mucosa através de microlacerações, principalmente na região anogenital e na cavidade orofaríngea. Não está perfeitamente determinado o tempo que o vírus resiste fora do organismo, embora a ocorrência de transmissão por meio de panos úmidos e utensílios sanitários contaminados sejam constatadas (Novaes, 2008).

A verruga genital clássica, também chamada condiloma acuminata, já foi descrita em épocas remotas e admitida por médicos na Grécia Antiga como "doença venérea". Sessenta por cento são de infecções anteriores e vinte e cinco por cento nunca se infectam pelo HPV (Rama, 2006).

Embora protuberantes, as lesões planas são mais elevadas em relação ao epitélio ao redor e têm superfície ondulada e com microespículas. Nas mulheres, as lesões condilomatosas localizam-se nas amiúdes no intróito vaginal, pequenos lábios, porções internas dos grandes lábios, vestíbulo, clitóris, vagina e cérvice. Nas regiões tegumentares e úmidas, os condilomas adquirem aspecto plano e de coloração mais escurecida. No homem, os condilomas são mais 
frequentes nas regiões úmidas, como glande, sulco coronal, frênulo e face interna do prepúcio (Ferraz et al., 2012).

O acometimento da uretra distal é relatado em cerca de $15 \%$ a $20 \%$ dos homens, enquanto nas mulheres ocorre em $5 \%$ dos casos. Já o envolvimento da área perianal e do canal anal é comum em ambos os sexos. Além da deformidade estética, a infecção clínica pelo HPV na área anogenital pode causar prurido, ardência, sangramento e dor durante o ato sexual. $A$ expressão "infecção subclínica por HPV", inicialmente restrita à presença do vírus na cérvice uterina, foi posteriormente utilizada para lesões da genitália externa não visíveis à vista desarmada, e sim sob visão microscópica após colocação de ácido acético a 5\%, caracterizada pelo aceto branqueamento. As lesões acetobrancas podem ser assintomáticas em ambos os sexos, ou provocas ardência, prurido, fissuras e ressecamento da genitália externa (Carvalho, 2018).

Tabela 1. Casos de cânceres atribuíveis a infecções em 2012.

\begin{tabular}{|c|c|c|c|c|c|c|c|}
\hline \multicolumn{8}{|c|}{ Peso global de cânceres atribuíveis a infecções em 2012: uma análise sintética } \\
\hline \multicolumn{2}{|c|}{ Número de novos casos } & $\begin{array}{l}\text { Proporção } \\
\text { de novos } \\
\text { casos } \\
\text { atribuíveis a } \\
\text { cada agente }\end{array}$ & \multicolumn{2}{|c|}{$\begin{array}{l}\text { Número de novos } \\
\text { casos atribuíveis à } \\
\text { infecção por sexo }\end{array}$} & \multicolumn{3}{|c|}{$\begin{array}{l}\text { Número de novos casos } \\
\text { atribuíveis à infecção por faixa } \\
\text { etária }\end{array}$} \\
\hline & & & Homens & Mulheres & $\begin{array}{l}<50 \\
\text { anos }\end{array}$ & $\begin{array}{c}50-69 \\
\text { anos }\end{array}$ & $\begin{array}{l}>70 \\
\text { anos }\end{array}$ \\
\hline Helicobacterpylori & 770000 & $35-4 \%$ & 500000 & 270000 & 91000 & 340000 & 330000 \\
\hline Humanpapillomavirus & 640000 & $29-5 \%$ & 66000 & 570000 & 270000 & 280000 & 90000 \\
\hline Hepatitis B vírus & 420000 & $19-2 \%$ & 300000 & 120000 & 84000 & 190000 & 140000 \\
\hline Hepatitis C vírus & 170000 & $7-8 \%$ & 110000 & 55000 & 26000 & 76000 & 66000 \\
\hline Epstein-Barrvirus & 120000 & $5-5 \%$ & 80000 & 40000 & 61000 & 44000 & 14000 \\
\hline $\begin{array}{c}\text { Humanherpesvirustype } \\
8 \\
\end{array}$ & 44000 & $2-0 \%$ & 29000 & 15000 & 32000 & 7600 & 4500 \\
\hline $\begin{array}{c}\text { Schistosoma } \\
\text { haematobium }\end{array}$ & 7000 & $0-3 \%$ & 4900 & 2200 & 1300 & 3700 & 2100 \\
\hline $\begin{array}{c}\text { Human T-cell } \\
\text { lymphotropicvírus } \\
\text { type } 1\end{array}$ & 3000 & $0-1 \%$ & 1700 & 1200 & 630 & 1200 & 1200 \\
\hline $\begin{array}{l}\text { Opisthorchis viverini } \\
\text { or Clonochissinenis }\end{array}$ & 1300 & $0-1 \%$ & 820 & 470 & 130 & 670 & 490 \\
\hline Allinfectiousagents & 2200000 & $100-0 \%$ & 1100000 & 110000 & 570000 & 950000 & 650000 \\
\hline
\end{tabular}

Fonte: Ginsburg (2016)

Rev. Psicol Saúde e Debate. Jul., 2019:5(1):80-109. 
Tabela 2.Estimativa sobre número de casos novos de câncer (2016)

\begin{tabular}{|c|c|c|c|c|c|}
\hline $\begin{array}{c}\text { Localização } \\
\text { Primaria }\end{array}$ & Norte & Nordeste & Centro Oeste & Sul & Sudeste \\
\hline Próstata & 2470 & 14290 & 5050 & 13.590 & 25.800 \\
\hline $\begin{array}{c}\text { Mama } \\
\text { Feminina }\end{array}$ & 1810 & 11190 & 4230 & 10.970 & 29.760 \\
\hline Colo do Útero & 1970 & 5630 & 1560 & 2240 & 4.940 \\
\hline $\begin{array}{c}\text { Traqueia, } \\
\text { Brônquio e } \\
\text { Pulmão }\end{array}$ & 1090 & 4790 & 1810 & 8040 & 12.490 \\
\hline Cólon e Reto & 920 & 4470 & 1330 & 6610 & 19.950 \\
\hline Estômago & 1450 & 4880 & 1340 & 3720 & 9.130 \\
\hline Cavidade Oral & 450 & 30170 & 890 & 2750 & 8.330 \\
\hline Laringe & 330 & 1740 & 510 & 1750 & 3.020 \\
\hline Bexiga & 460 & 1310 & 600 & 1860 & 5.440 \\
\hline Esôfago & 290 & 1880 & 700 & 3170 & 4.770 \\
\hline Ovário & 250 & 1420 & 530 & 990 & 2.960 \\
\hline $\begin{array}{c}\text { Linfoma de } \\
\text { Hodgkin }\end{array}$ & 180 & 450 & 210 & 660 & 970 \\
\hline $\begin{array}{c}\text { Linfoma não } \\
\text { Hodgkin }\end{array}$ & 400 & 1770 & 660 & 2060 & 5.350 \\
\hline $\begin{array}{c}\text { Glândula } \\
\text { Tireoide }\end{array}$ & 350 & 2270 & 400 & 1100 & 2.840 \\
\hline $\begin{array}{c}\text { Sistema } \\
\text { Nervoso } \\
\text { Central }\end{array}$ & 420 & 2210 & 700 & 2730 & 4.210 \\
\hline Leucemias & 560 & 2280 & 600 & 2200 & 4.430 \\
\hline Corpo do Útero & 230 & 1320 & 450 & 770 & 4.180 \\
\hline Pele Melanoma & 160 & 940 & 360 & 1950 & 2.260 \\
\hline $\begin{array}{c}\text { Outras } \\
\text { Localizações }\end{array}$ & 3400 & 16800 & 5150 & 31170 & 43.170 \\
\hline $\begin{array}{c}\text { Subtotal } \\
\text { Pele não } \\
\text { Melanoma }\end{array}$ & 17190 & 82710 & 28080 & 98330 & 194.000 \\
\hline \begin{tabular}{c} 
Total \\
\hline
\end{tabular} & 21490 & 107180 & 44430 & 131880 & 291.090 \\
\hline Instito & 24470 & 16350 & 33550 & 97.090 \\
\hline
\end{tabular}

Fonte: Instituto Nacional de Câncer [INCA] (2015)

\subsection{TRANSMISSÃO}

De acordo com Carvalho (2018), o HPV é altamente contagioso e pode contaminar com uma única exposição. Qualquer pessoa que tenha qualquer tipo de atividade sexual, incluindo contato genital, pode ser contaminado pelo o HPV. Embora seja raro, o vírus também pode se espalhar à mão, pele, objetos, toalhas, roupas íntimas e até o banheiro. Como muitas pessoas com HPV não apresentam sinais ou sintomas, elas não sabem que têm o vírus, mas podem transmiti-lo. De acordo com o especialista em doenças infecciosas e pesquisador do Oswaldo Cruz (Fiocruz), Edson Moreira Foundation, a infecção por HPV pode ocorrer mesmo sem penetração, porque o vírus também está na área genital.

É muito importante que as pessoas tenham acesso a informações sobre o vírus, fatores de risco e métodos de prevenção, tais como exames de Papanicolau e vacinas", explica ele.

Rev. Psicol Saúde e Debate. Jul., 2019:5(1):80-109. 
Estima-se que muitas pessoas contraiam HPV nos primeiros dois ou três anos de vida sexual ativa. Dois terços das pessoas que tiveram contato sexual com um parceiro infectado irão desenvolver uma infecção pelo HPV num prazo de três meses, de acordo com a Organização Mundial da Saúde (Novaes, 2008).

HPV também é transmitido por contato direto com a pele infectada ou membranas mucosas através da relação sexual. Também pode ser transmitido de mãe para filho no momento da entrega. A transmissão ocorre por contato direto com a pele infectada. O HPV é altamente contagioso e pode estar contaminado com uma única exposição. Qualquer pessoa que tenha qualquer tipo de atividade sexual, incluindo contato genital, pode receber o HPV (Castro, 2010).

Sabe-se que a via de transmissão materno-infantil pode ser direta, transplacentária e perinatal. Não está estabelecido o valor preventivo da operação cesariana, portanto, essa não deve ser realizada com o objetivo exclusivo de prevenir a transmissão do HPV para o recémnascido. A operação cesariana poderá ser indicada quando o tamanho e a localização das lesões estiverem causando obstrução do canal de parto ou quando houver risco de laceração das lesões e sangramento excessivo (Albring et al, 2006).

\subsection{INFECÇÃO VIRAL DO HPV}

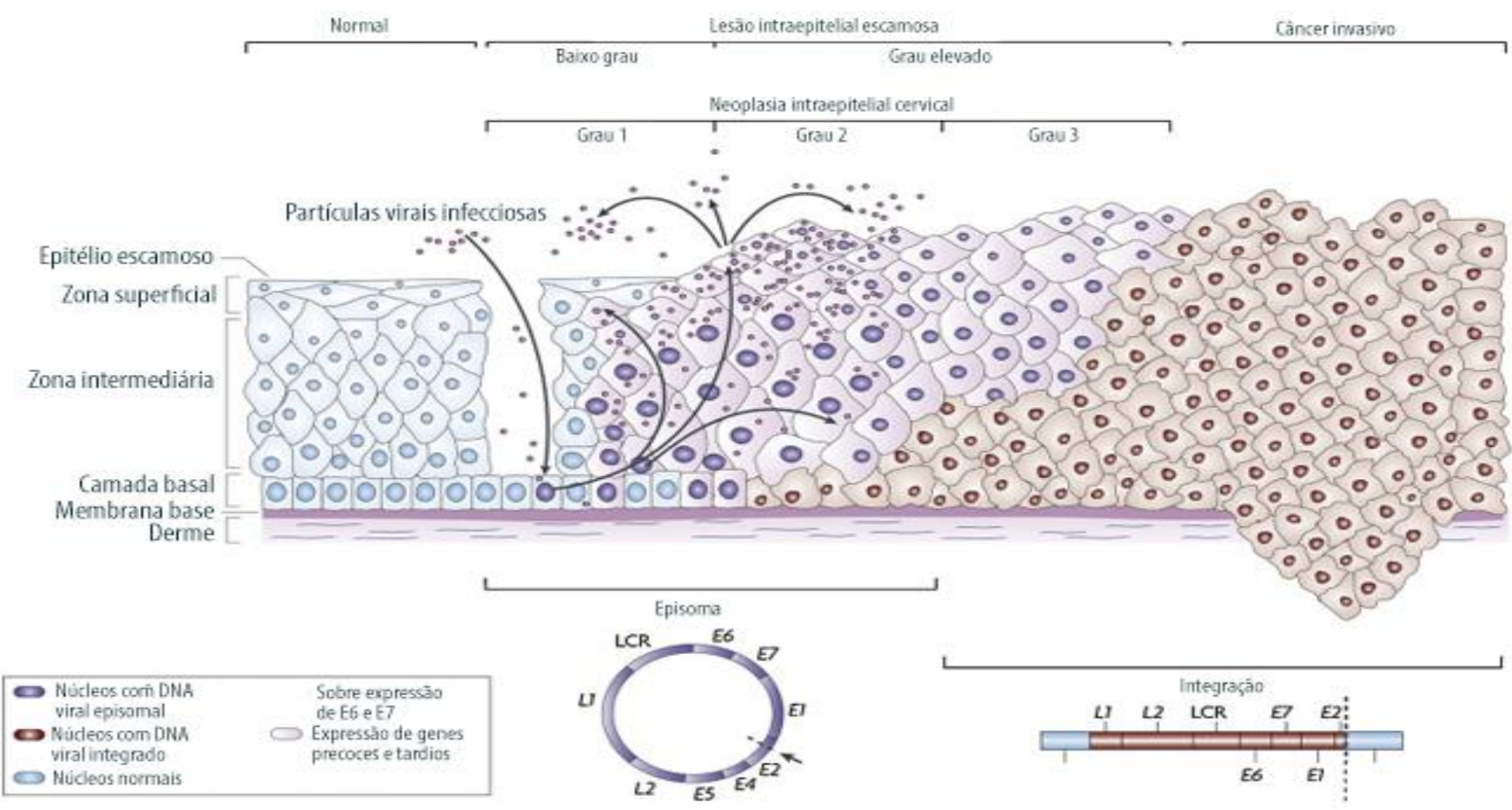

Figura 3. Infecção viral do HPV.

Fonte:Termini (2018)

Rev. Psicol Saúde e Debate. Jul., 2019:5(1):80-109. 
Partículas virais com DNA do HPV atingem a camada basal da derme, dando início a replicação viral primária. Acometendo as zonas intermediária e superficial do epitélio (Grau 1), dando início a neoplasia intraepitelial cervical. O DNA viral se integra ao DNA das células normais (Grau2). Expressão de genes precoces e tardios (Grau 3), presença de câncer invasivo (Burd, 2003).

Segundo Ferraz et al. (2012), após a infecção, o HPV ataca as células basais ou parabasais. O vírus começa sua replicação primária, acometendo este epitélio escamoso, com centenas de partículas virais maturas. Após penetração no citoplasma, a cápsula é total ou parcialmente removida e o genoma viral é exposto, espalhando-se de célula para célula. $O$ vírus entra no núcleo da célula e continua seu ciclo de replicação executando a transcrição do seu DNA em RNA. A transcrição é restrita às células epiteliais escamosas. Existe uma predileção para a pele e mucosas.

Seguindo a transcrição, o RNA transcrito é traduzido em proteínas $E$ (early) ou L (later). O genoma do HPV pode replicar em várias linhagens celulares indiferenciadas, quando as proteínas L1 e L2 se expressam. Somente a porção do vírus que alcança o núcleo sofre replicação. Ocorre o dano celular, a maturação, quando o vírus se torna infeccioso e a liberação, quando é eliminado da célula prolifera (Castro, 2010).

\subsection{SINTOMAS E MANIFESTAÇÃO CLÍNICA}

O principal sintoma do HPV é o surgimento de verrugas ou lesões na pele, normalmente manchas brancas ou acastanhada que coçam. Muitas vezes, no entanto, a lesão pode não ser visível, aparecendo em exames como colposcopia, vulvoscopia e peniscopia. Na mulher, as lesões costumam se desenvolver na vulva, vagina, colo do útero (Figura 03). No homem, o pênis é o local mais comum para aparecimento do HPV (Figura 04). Em ambos os gêneros, o ânus, garganta, boca (Figura 04), pés e mãos são locais em que o vírus do HPV costuma se manifestar (Cetinaet al, 2013).

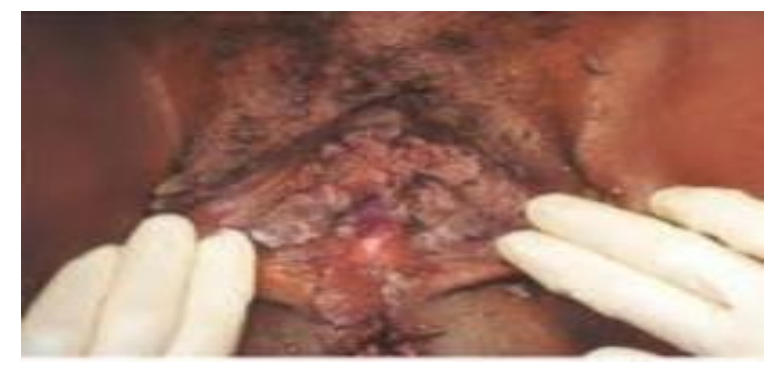

Figura 04. Lesões internas e externas na genitália feminina, presença de verrugas condilomas. Fonte:Carvalho (2018) 


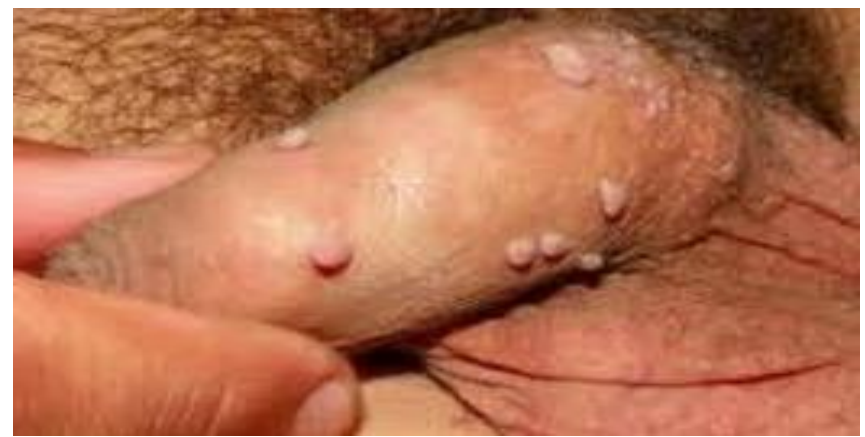

Figura 5. Lesões verrucosas em pênis, presença de condiloma, sinais clínicos. Fonte:Carvalho (2018)

\section{Sintomas do HPV Na boca}

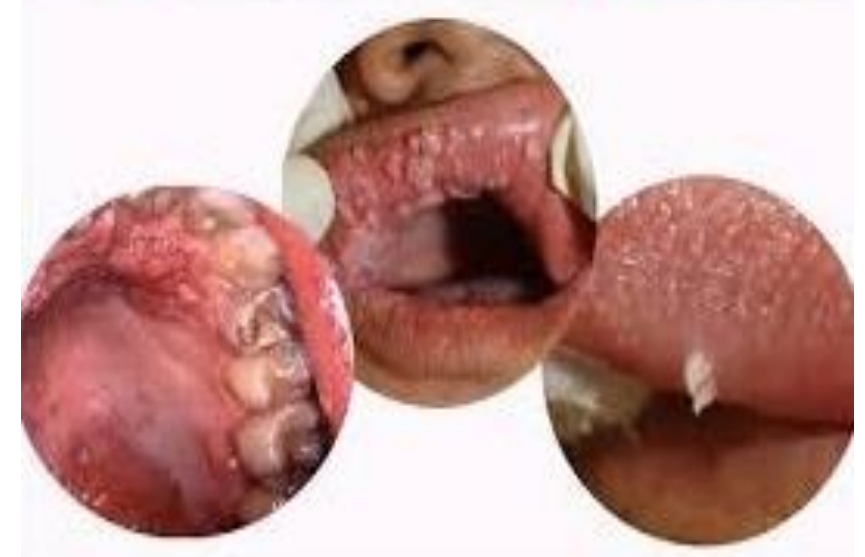

Figura 6. Manifestação clínica de lesões verrucosas na boca.

Fonte: Sedicias (2018)

\subsection{DIAGNÓSTICO LABORATORIAL}

\subsubsection{GENITOSCOPIA}

Com auxílio do colposcópio, que fornece aumento da imagem de até 20 vezes, é possível identificar lesões que são presumíveis de infecção pelo HPV. A realização da colposcopia, da vulvoscopia e da peniscopia utilizando-se de ácido acético, lugol e azul de toluidina, identifica a imagem suspeita, sendo de grande utilidade nos casos em que há necessidade de biópsia dirigida (Carvalho, 2018).

O teste de Schiller (visualização da lesão após colocação do lugol) é importante na diferenciação colposcópica entre o condiloma acuminado e o câncer cervical exofídico. A captação do lugol nos condilomas, em geral, é local, enquanto o câncer exofídico é iodo-negativo ou Schiller-positivo. Outros aspectos colposcópicos são admitidos como HPV-induzidos, como condilomas planos e colpite mosaiciforme, também encontrados no epitélio maduro da zona de 
transformação. As lesões intraepiteliais cervicais são achados colposcópicos anormais encontrados dentro da zona de transformação. Em geral, têm coloração avermelhada pela hipertrofia dos vasos do estroma e, após a colocação de ácido acético, tomam o aspecto de pontilhado e mosaico (Ferrazet al., 2012).

\subsubsection{CITOLOGIA}

A validação do exame, conforme Silva et al. (2007), depende de vários fatores, entre os quais são relacionados com: comparecer para coleta do exame sem estar menstruada, sem uso de qualquer medicação por via vaginal, além de abstinência sexual por 48 horas; a periodicidade do exame nos casos preventivos é anual ou, após dois exames anuais subsequentes sem anormalidade, a cada dois anos. Um profissional devidamente treinado e habilitado, utilizando espátula própria, deve recolher o material da endocérvice, da ectocérvice e do fundo de saco vaginal. Deve fazer um esfregaço não muito espesso em lâmina única e fixada em álcool absoluto, devidamente identificada.

De acordo com Burd (2003), o laboratório de análises deve utilizar corantes padronizados para a técnica de Papanicolau, proceder à montagem das lâminas. Após a feitura do screening por um citotécnico bem treinado, o citopatologista deve revisar os casos de emitir laudos com utilização de nomenclatura homogênea (sistema Bethesda). O diagnóstico de suspeição de infecção pelo papiloma vírus no esfregaço citológico é feito pelo achado do efeito citopático do vírus morfologicamente manifesto pela coilacitose. Além da coilocitose, critérios citológicos menos, como disceratose, paraceratose, metaplasia imatura atípica, binucleação, granulação citoplasmática e células giriniformes, são sugestivos da infecção pelo HPV. Na coilocitose verdadeira, considerada como sinal patognomônico da infecção pelo HPV, devem existir halos citoplasmáticos perinucleares e atipia nuclear (Castro, 2010).

\subsubsection{HISTOPATOLOGIA}

O efeito citopático da infecção pelo HPV - coilocitose - também pode ser identificado em cortes histológicos e na dependência das camadas celulares comprometidas e das alterações nucleares. As lesões intraepiteliais são classificadas como de baixo e de alto grau. Nas lesões de baixo grau (NIC I), ocorre perda da polaridade e maturação na camada basal do epitélio. Já nas lesões de alto grau (NIC II e NIC III), as lesões celulares ocorrem nas três camadas (Albringetal., 2006).

\subsubsection{IMUNO-HISTOQUÍMICA}

Rev. Psicol Saúde e Debate. Jul., 2019:5(1):80-109. 
Utilizando-se anticorpos policlonais, é possível identificar, à microscopia óptica, antígenos específicos de vários tipos de HPV. O teste tem alta especificidade, pode ser aplicado em blocos de parafina ou esfregaços citológicos e detecta os HPVs na fase de baixo grau e condilomas. Nas lesões intraepiteliais de alto grau e nos carcinomas invasivos, quando ocorre a integração de genoma viral à célula hospedeira, há reduzida sensibilidade do teste (Novaes, 2008).

\subsubsection{MICROSCOPIA ELETRÔNICA}

Devido à sua complexidade, em virtude dos custos do aparelho e do treinamento necessário ao profissional para sua execução, este exame somente tem sido utilizado em protocolos de pesquisas. Sua contribuição tem sido importante para o esclarecimento da relação entre o HPV e a célula hospedeira, além de esclarecer a patogenia das lesões (Novaes, 2008).

\subsubsection{BIOLOGIA MOLECULAR}

Este método permite a identificação do DNA do HPV na lesão e é padrão-ouro no diagnóstico da infecção pelo papiloma vírus. Pode ser realizado pelas técnicas de hibridização in situ, captura híbrida e PCR (Ferraz et al., 2012). A hibridização molecular in situ é um processo no qual são detectadas sequências especificas de DNA ou RNA, utilizando-se uma sequência de ácidos nucléicos marcada com cromógenos, que pode ser realizado em cortes de tecidos ou preparados citológicos. É possível, por este método, estabelecer os tipos de HPV de acordo com seu potencial oncogênico. No processo de captura híbrida em microplaca são utilizados anticorpos em solução hibridizadora, detectáveis por quimioluminescência. Dezoito tipos de HPV encontrados com mais frequência no trato anogenital são detectados por este processo. São utilizadas sondas para o grupo A, que possui HPV de baixo risco $(6,11,42,43$ e 44), e o grupo $B$, que possui sondas para os HPVs de risco indeterminado/alto risco $(16,18,31,33,35,39,45$, $51,52,56,58,59$ e 68). Além de especificar o tipo de HPV, é possível quantificar a carga viral (Ferraz et al., 2012).

\subsection{PCR}

A técnica de PCR permite também a identificação de tipos virais ainda não conhecidos, além da caracterização de variantes virais, quando complementadas pelo estudo de sequenciamento automatizado (Ferraz et al., 2012). Já foram identificadas no mundo 16 variantes do HPV 16 e, no Brasil, o estudo filogenético realizado em São Paulo, por Castro 
(2010), isolou sete diferentes variantes do HPV 16 de braços filogenéticos não-europeus, que apresentaram tendência a persistir por mais tempo e forte associação com NIC.

O HPV 16 é o tipo prevalente em lesões neoplásticas cervicais, identificado em 46,9\% das portadoras de NIC, em estudo realizado no Hospital das Clínicas da UFPE, no qual $70 \%$ das pesquisadas tinham lesão de alto grau de HPV 16 variantes. A relação entre HPV e NIC foi mais bem-esclarecida com a utilização de técnica de PCR, que possui elevadas sensibilidades e especificidade. $O$ método permite a ampliação de um segmento especifico de DNA viral e posterior tipagem com a utilização de enzimas restritivas. É, portanto, um método qualitativo apesar de já ser possível a quantificação do HPV 16 por PCR (Black, 2002).

Recentemente, a Food and Drug Administration (FDA) aprovou a utilização do teste de HPV em conjunto com a colpocitologia na prevenção do câncer cervical. Esta aprovação referese à Captura Híbrida II, que detecta apenas HPV de alto risco, em substituição ao uso da Captura Híbrida I, com potencial para identificar, também, HPV de baixo risco, reconhecido hoje como impróprio na prevenção das neoplasias cervicais (Ferraz et al., 2012).

Observa-se, atualmente, considerável aumento de solicitação dos testes de HPV como prevenção das neoplasias cervicais, em alguns casos, antecipada ao estudo citomorfológico, inclusive para mulheres jovens, maiores portadoras de infecção transiente (Castro, 2010).

A disponibilidade dos testes para HPV, como método adjuvante à citopatologia na prevenção das neoplasias cervicais, é um importante avanço, porém, até o momento, não há dados comprobatórios suficientes de que esta combinação promoverá melhores resultados, redução dos custos ou melhor aceitação pelas mulheres do que a colpocitologia isolada, sobretudo em países em desenvolvimento. Os estudos atuais demonstram elevadas sensibilidade e especificidade dos exames de colpocitologia em conjunto com o DNA-HPV, em pacientes com idade superior a 30 anos e também naquelas em que há discordância nos resultados dos exames morfológicos (Rama, 2006).

Segundo Black (2002), PCR (Reação em Cadeia de Polimerase), consiste na amplificação do DNA viral (HPV). Esta técnica é usada em tubos de ensaio contendo o DNA e mais alguns compostos necessários, como primers (DNAs iniciadores ou iniciadores) e a enzima DNA polimerase (enzima que faz a replicação do DNA). Os primers são fitas de DNA, com mais ou menos 20 bases ( $A, T, C, G$ ) complementares, ou seja, ligam-se ao início da sequência de DNA que se quer multiplicar. Quando uma molécula de DNA vai ser multiplicada deve-se separar a dupla fita, formando, assim, duas fitas diferentes, mas complementares entre si. Cada fita servirá de molde para a duplicação, por isso, são necessários dois tipos de primers diferentes. Quando houver DNA detectado em alguma amostra, o teste possibilita a identificação do genótipo do HPV através de regiões precisas para vírus de alto e baixo grau.

Por esta técnica ter uma sensibilidade maior, e por sua eficácia, a técnica pode ser Rev. Psicol Saúde e Debate. Jul., 2019:5(1):80-109. 
utilizada principalmente para um diagnóstico precoce do HPV, sendo assim, comparada a outras técnicas, ela vem sendo utilizada nos laboratórios frequentemente, com intuito de liberar um resultado com maior rapidez e sensibilidade (Ferraz et al, 2012).

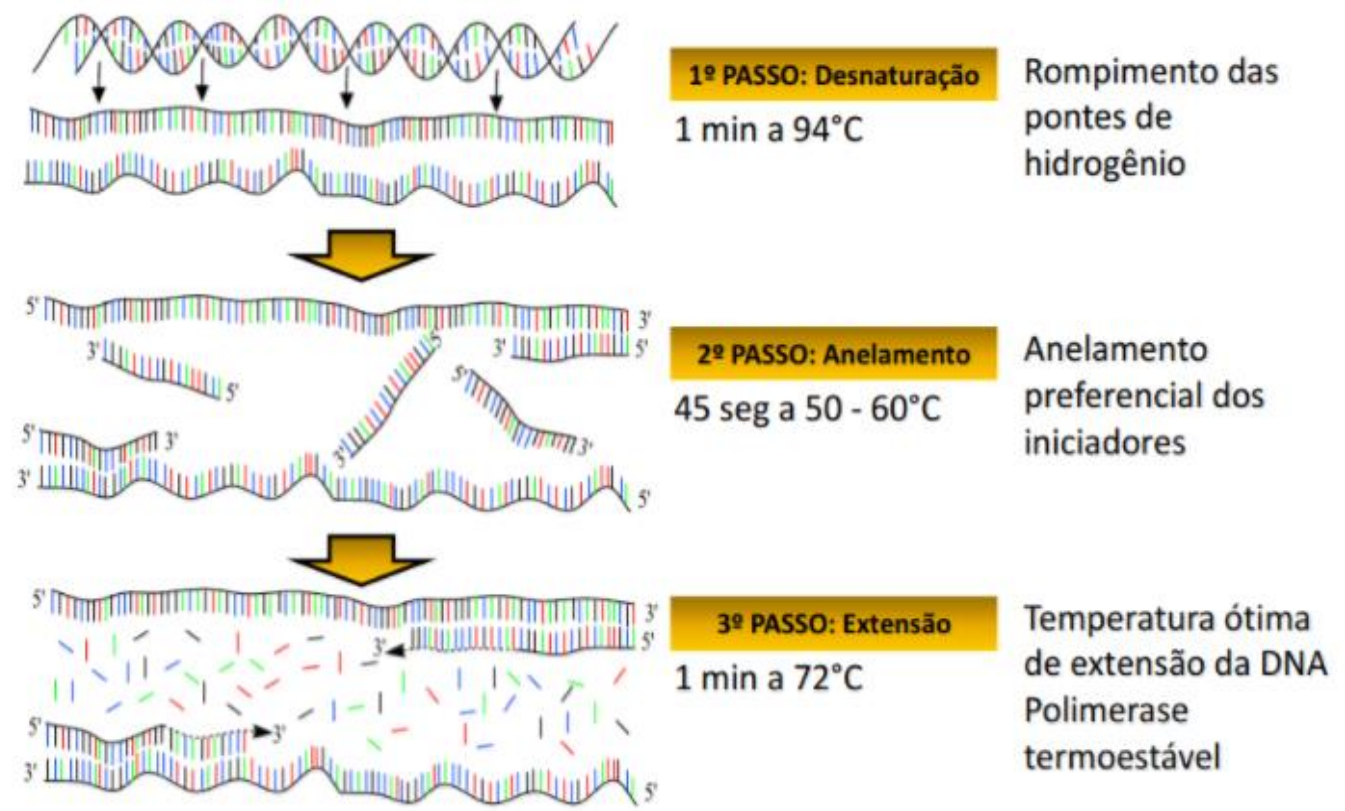

Figura 07. Explicação da técnica de PCR.

Fonte: Cetina et al. (2013)

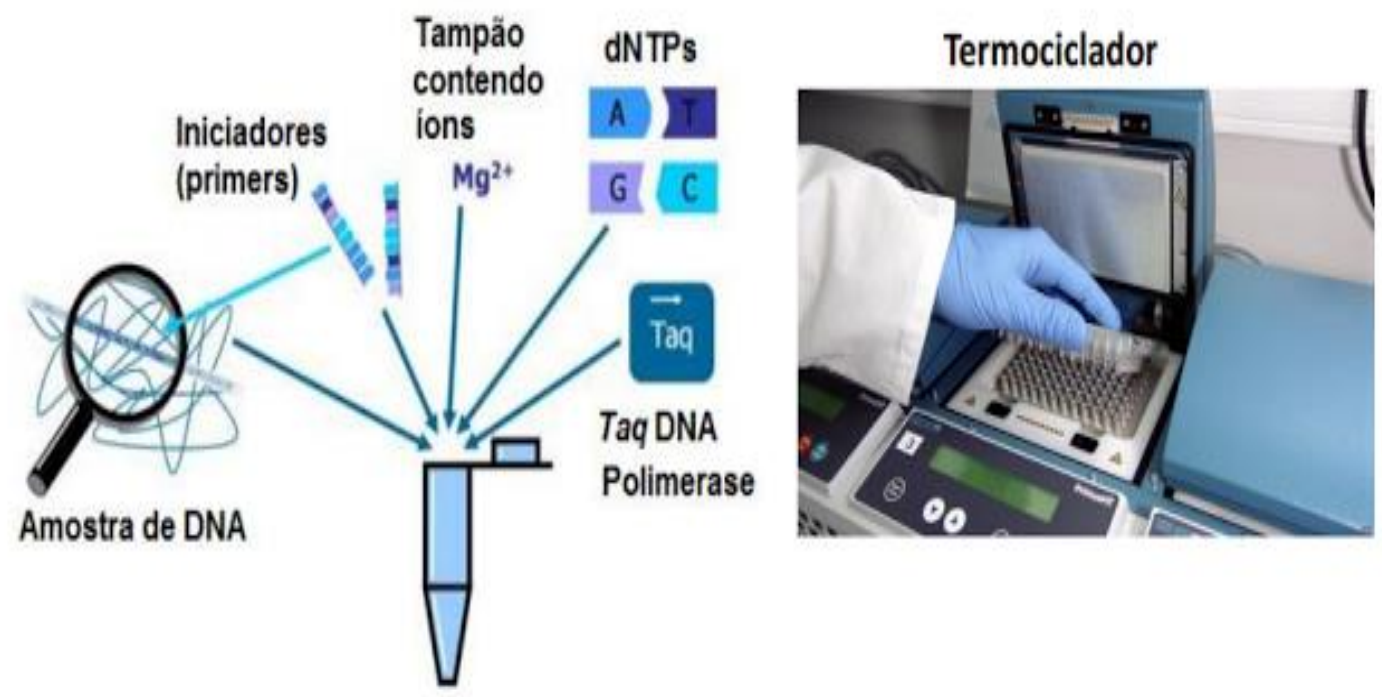

Figura 08. Preparação da amostra de DNA.

Fonte: Cetina et al. (2013) 
Adição de primers e dNTPSs (com nucleotídeos) junto a amostra de DNA, que irão aturar na reação. Ao final adiciona-se a enzima TaqDNA polimerase, que por fim é inserido no termocliclador para a realização da técnica de PCR (Ginsburg, 2016).

\subsection{DIAGNÓSTICO MOLECULAR DO HPV}

Segundo os métodos de diagnóstico de infecção por HPV, os baseados em PCR têm a maior sensibilidade de detecção dos genomas virais quando comparados a outras metodologias. Por intermédio da PCR, é possível detectar e identificar o material genômico dos HPVs, o que permite saber se o vírus é de alto ou baixo risco oncogênico. Assim, o diagnóstico por PCR representa um complemento importante aos diagnósticos cito-histopatológicos e colposcópicos (Ferraz et al., 2012).

Atualmente, existem várias modificações da técnica de PCR convencional, sendo as principais a PCR em Tempo Real ou Q-PCR (PCR quantitativa), RT-PCR (PCR por Transcrição Reversa, para se amplificar amostras de RNA) e a PCR Multiplex, a qual pode ser aplicada para a amplificação de vários loci em uma mesma reação. Para a detecção de HPV, a Q-PCR promove uma análise qualitativa e quantitativa, o que permite a estimativa da carga viral de uma amostra biológica. Esta técnica difere da PCR convencional por utilizar sondas marcadas com fluoróforos que emitem uma fluorescência durante as amplificações, e o sinal é detectado por um laser do termociclador (Novaes, 2008). O resultado pode ser visualizado em uma tela de computador. A PCR convencional pode ser considerada o método mais sensível disponível, mas possui algumas limitações, sendo assim, não é possível quantificar de maneira significante a carga viral. De acordo com Silva et al. (2007), da Revista Paulista de Medicina, devido à alta sensibilidade do método de PCR, podem ocorrer resultados falso-positivos, ocasionados por contaminação do ambiente de trabalho por DNA amplificado. Esta restrição pode ser evitada com o uso da QPCR. A Q-PCR realiza a quantificação dos ácidos nucleicos de maneira precisa e com maior reprodutibilidade. Ela possibilita maior facilidade na quantificação, possui maior sensibilidade, precisão, reprodutibilidade, e maior velocidade na análise. A liberação de fluorescência a cada ciclo de amplificação é diretamente proporcional à quantidade gerada, sendo considerado um método preciso de avaliar a carga viral e é projetado para manter a contaminação a um mínimo. A sensibilidade e especificidade do método PCR pode sofrer variações dependendo dos primers ("iniciadores", em português), do tamanho de produto da PCR, desempenho da DNA polimerase utilizada na reação e da quantidade de DNA do HPV amplificado (Tacla, 2008).

Os produtos amplificados por PCR podem ser clivados com enzimas de restrição e os fragmentos obtidos são comparados para identificação do subtipo viral, o que classifica seu grau de risco. Este método apresenta vantagens em relação aos demais testes disponíveis, pois 
enquanto nos outros métodos o poder de detecção é de no máximo uma partícula viral em cada 10 células normais, a PCR é capaz de detectar 1 partícula viral em cada 1000 células; a técnica permite, também, verificar infecções por múltiplos tipos e avaliar o risco oncogênico da população viral infectante. No entanto, a análise do DNA do HPV por PCR tem um baixo valor falso-negativo para predizer lesões cervicais relacionadas com HPV (Ferraz et al., 2012).

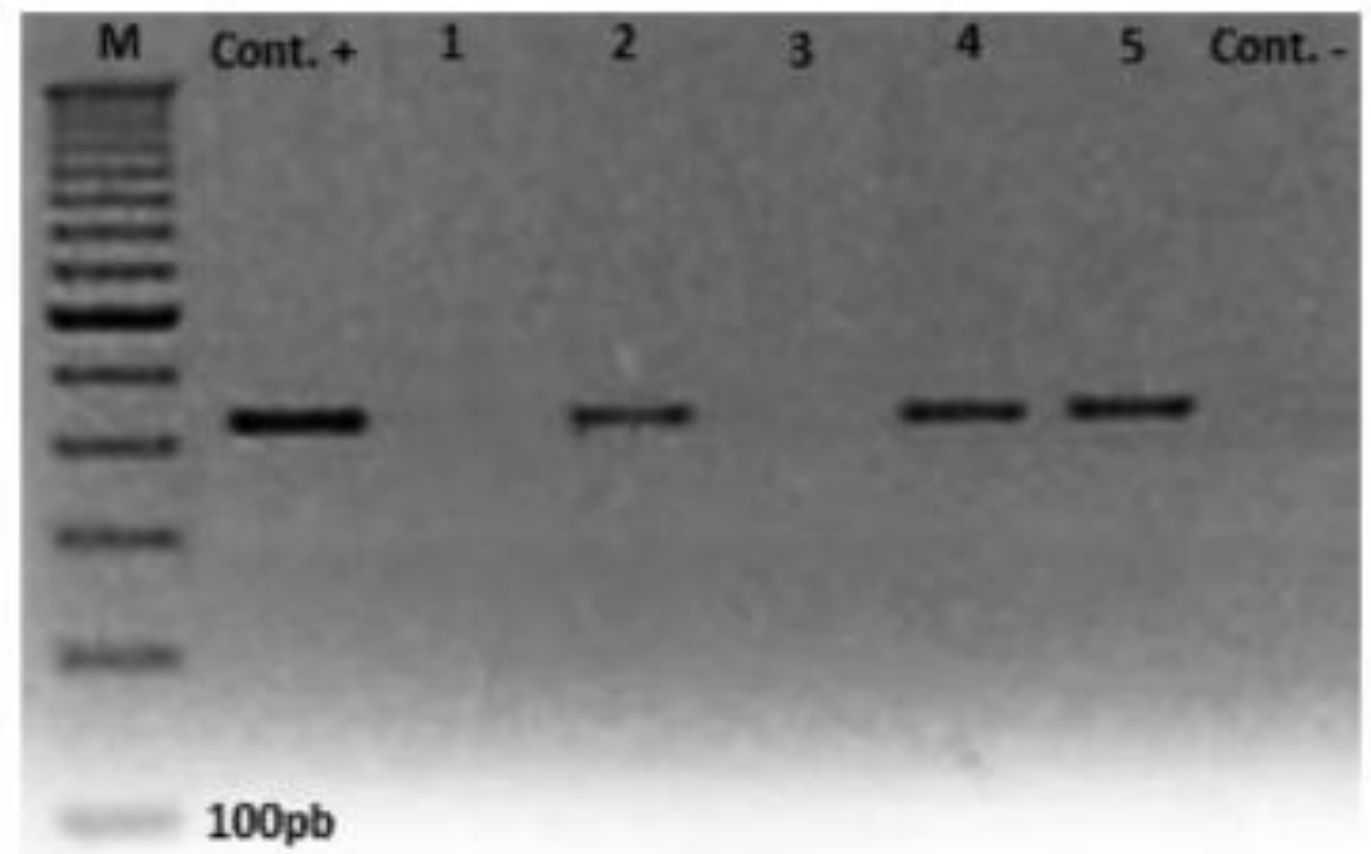

Figura 1 - Amplificaçāo do material genético viral correspondente à região conservada do gene L1 do Papilomavírus Humanos (HPV). M: marcador de 100pb; Cont. +: controle positivo da presença do DNA-HPV; Linhas 1 e 3 confirmaçāo da ausência do material genético viral; Linhas 2, 4 e 5 confirmaçāo do material genético viral do HPV; Cont.- : controle de contaminação da reação.

Figura 9. Amplificação da amostra de DNA HPV, realizada pela técnica de PCR. Fonte:Santos et al. (2013) 


\subsection{DIAGNÓSTICO MOLECULAR DO HPV}

\begin{tabular}{|c|c|c|c|c|}
\hline TESTE & SENSIBILIDADE & ESPECIFICIDADE & $\begin{array}{l}\text { FACILIDADE } \\
\text { PARA O TESTE }\end{array}$ & COMENTÁRIOS \\
\hline Southern Blot & Alta & Alta & Fraca & $\begin{array}{l}\text { Excelente para pesquisa e controle de qualidade, porém } \\
\text { muito demorado e de dificil uso na clínica diária. }\end{array}$ \\
\hline Dot Blot & Moderada & Alta & Boa & Rápido e relativamente barato. \\
\hline Hibridização in situ & Moderada & Alta & Boa & Localiza DNA do HPV em tecidos. \\
\hline $\begin{array}{l}\text { Hibridização in situ } \\
\text { com filtro }\end{array}$ & Fraca & Fraca & Boa & Simples execução, porém pouco preciso. \\
\hline PCR & Muito alta & Alta & Boa & $\begin{array}{l}\text { PCR Procedimento "Real Time" Sistema fechado com } \\
\text { proteção bioquimica de UDG = "Gold Standard" = } \\
\text { Sensibilidade + Especificidade + Exatidão. }\end{array}$ \\
\hline Captura hibrida & Alta & Alta & Boa & Rápido e pode ser usado na clínica diária. \\
\hline
\end{tabular}

Figura 10. Comparação das técnicas moleculares de diagnóstico do HPV.

Fonte: Carvalho (2018)

Quando localizado na genitália externa, é constituído de proliferação epiteliais papilíferas, por isso, o condiloma etofídico é de fácil diagnóstico clínico. Por outro lado, lesões previamente tratadas, lesões antigas e queratinizadas ou sangrantes e com infecção bacteriana secundária dificultam o diagnóstico. Em três casos, a biópsia deve ser realizada, principalmente na diferenciação com o carcinoma verrugoso. Diversos tumores benignos que podem surgir nos genitais devem ser diferenciados do condiloma acuminado, como pólipos fibropiteliais e acrocórdons (Ferrazet al. 2012). Fisiologicamente, podem ser encontradas na face interna dos pequenos lábios projeções digiformes não coalescentes, que são papilas vestibulares proeminentes. Do mesmo modo, a corona radeata - projeções papilomatosas proeminentes e não coalescentes - ao longo do sulco balanoprepucial -, também deve ser diferenciada do condiloma no sexo masculino. As lesões, ou condiloma plano do secundarismo sifilítico, com frequência, requerem diagnóstico diferencial. Em tais casos, os testes não treponêmicos (VDRL) são positivos e as lesões desaparecem após antibioticoterapia (Ginsburg, 2016).

\section{PREVENÇÃO E TRATAMENTO}

Segundo o Ministério da Saúde (2014), existem duas vacinas contra o HPV: a vacina quadrivalente (HPV 6, 11, 16, 18) da Merck Sharp \& Dohme (MSD), e a vacina bivalente (HPV $16,18)$ da GlaxoSmithKline (GSK). A vacina quadrivalente contra HPV é proposta em doses, esquema 0, 2, 6 meses: data escolhida ( $1^{\mathrm{a}}$ dose), 60 dias ( $2^{\underline{a}}$ dose) e 180 dias ( $3^{\underline{a}}$ dose). A vacina 
bivalente também é administrada em três doses, esquema 0, 1,6 meses: data escolhida (1 dose), 30 dias ( $2^{-a}$ dose) e 180 dias ( $3^{\underline{a}}$ dose). Meninas de 9 a 14 anos podem ser vacinadas e meninos de 11 a 14 anos também.

De acordo com Varela (2009), o tratamento para as verrugas genitais pode ser feito por laser, crioterapia (congelamento) ou cirurgia com uso de anestésicos locais. Podem ser utilizadas substâncias químicas diretamente nas verrugas. Para situações de câncer de colo de útero, conforme autor citado acima, o tratamento depende do estágio do câncer. Quando restrito ao revestimento do colo do útero, o médico pode conseguir removê-lo completamente, por meio de bisturi ou excisão eletrocirúrgica.

Como o câncer pode reincidir, os médicos aconselham as mulheres a retornarem ao controle e à realização do exame de Papanicolau e da colposcopia a cada seis meses. Quando o câncer se encontra em um estágio mais avançado, a histerectomia radical (cirurgia para a retirada do útero e das estruturas adjacentes) e a remoção dos linfonodos são necessárias (Carrillo, \& Goldenberg, 2014)

A radioterapia é altamente eficaz no tratamento do câncer de colo do útero avançado que não se disseminou além da região pélvica. Apesar de a radioterapia geralmente não provocar muitos problemas imediatos, pode irritar o reto e a vagina. Uma lesão tardia da bexiga ou do reto pode ocorrer e, geralmente, os ovários deixam de funcionar. Quando há disseminação do câncer além da pelve, a quimioterapia é, por algumas vezes, recomendada (Campisi et al., 2015).

Porém, devido ao impacto psicológico causado pela doença, novas formas de intervenção estão sendo desenvolvidas no âmbito da Psicologia, que apresentada com o objetivo de informar, tratar, identificar os causadores de stress que podem influenciar diretamente no processo de tratamento, bem como planejar um acordo psicossocial ao paciente, abrangendo a família e equipe de saúde. Esse segmento da Psicologia, denominado Psico-oncologia, tem tido maior representatividade nos serviços de saúde em todo o mundo, seja em hospitais e clínicas de oncologia, centros de apoio e tratamento de oncologia e outros centros de assistência oncológica (Fonseca, \& Castro, 2016)

\section{DISCUSSÃO DE DADOS EM LITERATURA COMPARATIVA}

Foi realizado um estudo em 2010, no Laboratório de Bioquímica e Biologia Molecular UNIFESP, em que 33 amostras de carcinoma de mulheres diagnosticadas com HPV por citopatologia e histologia para um estudo comparativo da detecção de amostras com a técnica de PCR foram recolhidos. Os fragmentos foram amplificados num termociclador sob as seguintes condições: desnaturação inicial a $95^{\circ} \mathrm{C}$ durante 5 minutos, 40 ciclos de desnaturação a $95^{\circ} \mathrm{C}$ Rev. Psicol Saúde e Debate. Jul., 2019:5(1):80-109. 
durante 1 minuto, emparelhamento a $55^{\circ} \mathrm{C}$ durante 1 minuto e extensão a $72^{\circ} \mathrm{C}$ durante 2 minutos, extensão final a $72^{\circ} \mathrm{C}$ durante 8 minutos. Para verificar a presença de DNA humano, foi testada eletroforese em gel de $2 \%$ de agarose corado com brometo de etídio em tampão TBE 1X (Tris, ácido bórico, ácido etilenodiaminotetraacético [EDTA] e fonte eletroforética durante 1 hora a 100 volts (Castro, 2010). A visualização foi realizada sob luz ultravioleta. Após confirmação da presença e da integridade do DNA genómico por amplificação por PCR de bglobina, as amostras foram sujeitas a seleção de genes de HPV por dois métodos: por PCR e PCR com iniciadores oligonucleotidicos para DNA e HPV (Castro, 2010).

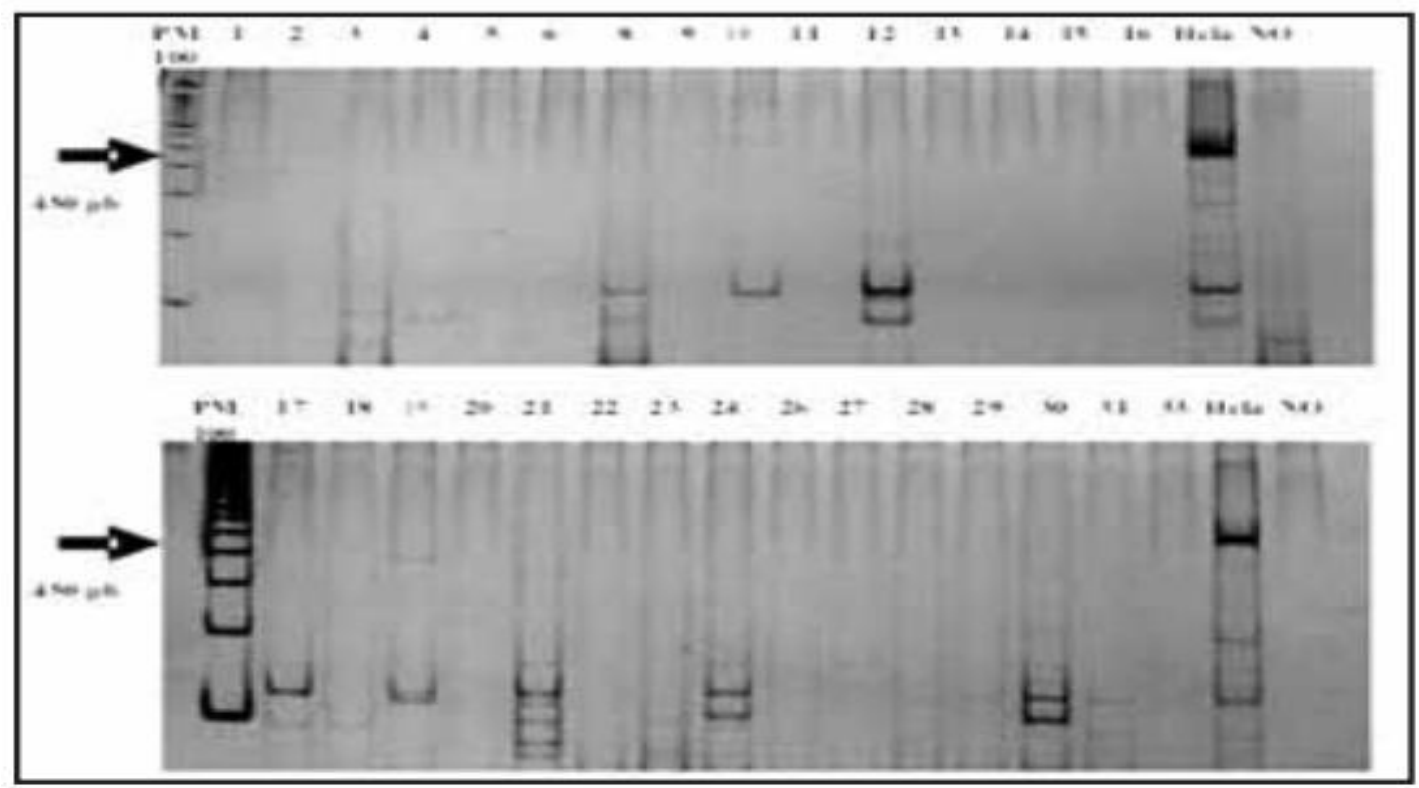

Figura 1 - Eletroforese em gel de poliacrilamida a $8 \%$ mostrando resultado da amplificação do HPV (450 pb) por PCR nas 30 amostras de carcinoma epidermoide de lábio PM 100 = padrão de tamanho molecular (100 pb DNA Ladder, Invitrogen); linhagem de células HeLa = controle positivo para DNA do HPV; NO = controle negativo, sem DNA.

Figura 11. Eletroforese em gel de poliacrilamina a $8 \%$ Fonte: Ministério da Saúde [MS] (2014)

A análise das amostras por meio da PCR permitiu a detecção do DNA do HPV nas amostras $1,2,5,6,10,12,16,24,28,29,30,31$ e 33 , correspondendo a 43,33\% (13 de 30 amostras). 


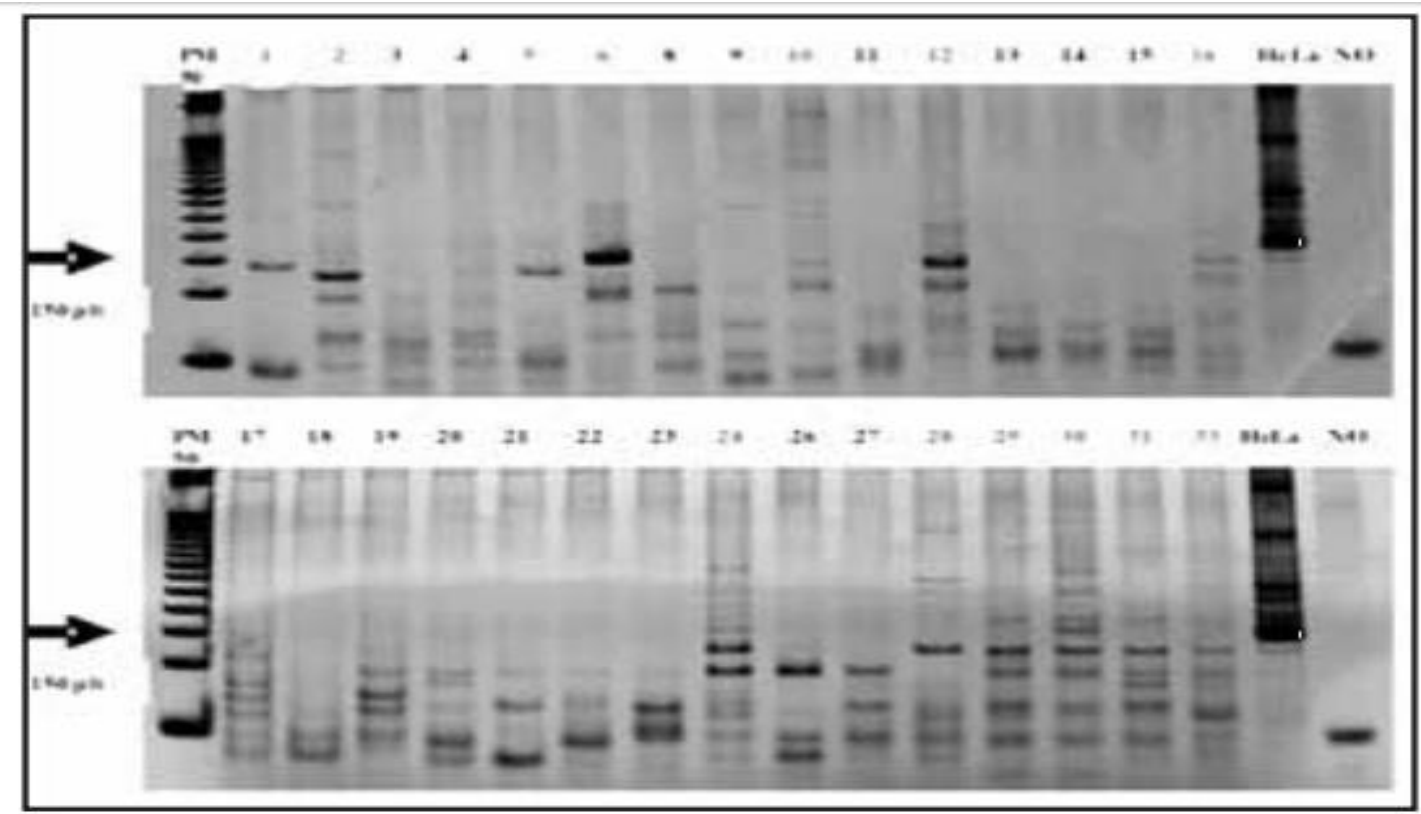

Figura 2 - Eletroforese em gel de poliacrilamida a $8 \%$ mostrando resultado da amplificação do HPV (150 pb) por PCR nas 30 amostras de carcinoma epidermoide de lábio. PM 50 = peso molecular de 50 pb (50 pb DNA Ladder, Invitrogen); linhagem de células HeLa = controle positivo para DNA do HPV; NO = controle negativo, sem DNA.

Figura 12. Eletroforese em gel de poliacrilamina a $8 \%$ Fonte: MS (2014)

Estas distinções na deteç̧ão do DNA do HPV sugerem uma diferença potencial na habilidade para amplificar fragmentos de diferentes tamanhos e tipos específicos de HPV de acordo com os métodos de detecção de DNA utilizados e também podem ser resultado dos tipos de material estudados (esfregaços, material congelado, material parafinado), da localização anatômica, de questões populacionais e desenho dos oligonucleotídeos (Albring et al., 2006).

Neste estudo, compararam a PCR, utilizando os pares de oligonucleotídeos MY09/MY11 e GP5/GP6 e a PCR com MY/GP. Com a utilização dos oligonucleotídeos MY09/MY11 na PCR, o DNA do HPV foi detectado em $26,3 \%$ dos casos de citologia exfoliativa com alterações patológicas. Pelo uso da nPCR, esta eficiência aumentou para 84,2\% nestes espécimes (Albring et al., 2006).

\section{CONCLUSÃO}

Pode-se concluir com este trabalho que as DSTs (doenças sexualmente transmissíveis), tornaram-se doenças bastantes pesquisadas entre os cientistas de todo o mundo, e com o avançar do conhecimento científico e tecnológico, a população tem maior acesso as informações de forma clara. Assim, atualmente, preocupa-se com a precocidade da vida sexual, falta de 
prevenção e o não uso de métodos contraceptivos, fazendo, desta forma, que haja um aumento do número de DSTs, que, em grande maioria, compromete o funcionamento do corpo humano, como é o caso do Papiloma vírus humano (HPV).

Os HPV podem ser classificados em tipos de baixo e de alto risco de câncer. Os HPV tipos 6 e 11, que são considerados de baixo risco, não possuem risco para malignidade, pois os vírus de alto risco tipos 16, 18, 31, 33, 45, 58 estão associados a lesões pré-cancerígenas. Segundo a Organização Mundial de Saúde, a transmissão do Papiloma Vírus Humano (HPV) é por contato direto com a pele infectada. São transmitidos por meio das relações sexuais, podendo causar lesões na vagina, colo do útero, pênis e ânus, podendo haver manifestação clínica ou não, dependendo de condições favoráveis para seu desenvolvimento.

infecção pelo HPV é endêmica entre os indivíduos sexualmente ativos e as infecções pelo Papiloma Vírus Humano vem aumentando significativamente. O diagnóstico da infecção por HPV é obtido pela detecção dos seus efeitos morfológicos sobre a citologia e histopatologia, ou do seu ácido desoxirribonucléico (DNA) e o tratamento deve ser feito conforme orientação medica, sendo a prevenção a melhor maneira de se evitar o HPV.

\section{REFERÊNCIAS}

Albring, L., Brentano, J. E., \& Vargas, V. R. A. (2006). O câncer do colo do útero, o Papiloma Vírus Humano (HPV) e seus fatores de risco e as mulheres indígenas Guarani. Revista Brasileira de Análises Clínicas, 38(2), 87-90.

Black, J. G. (2002). Microbiologia Fundamentos e Perspectivas.4a ed. Rio de Janeiro: Editora Guanabara Koogan.

Burd, E. M. (2003). Human Papillomavirus and cervical câncer. Clinical Microbiology Reviews, 16(1), 1-17.

Campisi, G., Giovanelli, L., \& Ammatuna, P. (2015). Human papilomavírus frequency in oral ephitelial lesions. Jornal of Oral Pathology \& Medicine, v. 34, n. 1, p. 62-4.

Carrillo, G. J. S., \& Goldenberg, P. (2014). Conhecimentos e Práticas de Jovens Sobre a Infecção pelo Papiloma Vírus Humano: uma questão re-atualizada. Revista Colombiana de Obstetricia y Ginecología, 65(2), 152-161.

Carvalho, J. C. (2018). HPV- Ginotipagem e biologia molecular. Recuperado em 04 agosto, 2018, de http://www.hpvonline.com.br/sobre-hpv/hpv-e-diagnostico/hpv-genotipagem-e-biologiamolecular/

Castro, L. F. (2010). Exame Papanicolau:o conhecimento das mulheres sobre o preventivo e a estratégia do PSF no combato ao câncer de colo de útero. Trabalho de Conclusão de Curso, Faculdade de Medicina, Universidade Federal de Minas Gerais, Uberaba, Minas Gerais. $\begin{array}{lllll}\text { Recuperado } & \text { em } & 23 & \text { abril, } & \text { 2018, }\end{array}$ http://www.nescon.medicina.ufmg.br/biblioteca/imagem/2318.pdf.

Cetina, C., Dizib, B., López, M., Nuñez, M. J., Rodriguez, J., Romero, A., \& Villasenor, M. (2013). Reaccionencadena de lapolimerasa. Recuperado em 19 julho, 2018, de https://es.slideshare.net/majonm1/reaccin-en-cadena-de-la-polimerasa-28788553

Ferraz, L. C., Santos, A. B. R., \& Discacciati, M. G. (2012). Ciclo celular, HPV e evolução da neoplasia intra-epitelial cervical: seleção de marcadores biológicos. Jornal Health Science do Instituto de São Paulo,30(2), 107-111. 
Fonseca, R., \& Castro, M. M. (2016). A Importância da Atuação do Psicólogo junto a Pacientes com Câncer: uma abordagem psico - Oncológica. Revista Psicologia e Saúde em Debate, 2(1), $54-72$.

Ginsburg, O. (2016). Global Disparities in HPV vaccination. Comment, 4, 428-429. Recuperado em 15 julho, 2018, de https://www.thelancet.com/journals/langlo/article/PIIS2214109X(16)30107-3/fulltext

Graça, A. (2018). HPV (Human Papiloma Virus). Recuperado em 22 junho, 2018, de https://www.centromedicofreicaneca.com.br/hpv-human-papiloma-virus/.

HPV: Vírus do Papiloma Humano. (2018). Recuperado em 18 julho, 2018, de https://saudesublime.com/hpv/

International Agency for Research on Cancer. (2005). Handbooks of Cancer Prevention: Cervix Cancer Screening. Lyon: IARC.

Instituto Nacional de Câncer José Alencar Gomes da Silva. (2015). Estimativa 2016: incidência de câncer no Brasil. Rio de Janeiro: INCA.

Ministério da Saúde. (2014). Guia Prático sobre HPV: guia de perguntas e respostas para profissionais de saúde. Brasília: MS.

Novaes, H. M. D. (2008). A vacina contra HPV e o Câncer de colo de útero: desafios para a sua incorporação em sistemas de saúde. Revista Brasileira de Epidemiologia, 11(3), 505 - 525.

Paiva, R. V. S. (2018). Conhecer para prevenir o HPV. Recuperado em 25 junho, 2018, de http://rede.novaescolaclube.org.br/planos-de-aula/conhecer-para-prevenir-o-hpv

Palefsky, J. (2008). Human papillomavirus and anal neoplasia. Current Opinion in HIV and AIDS, 5(2), 78-85.

Pereiyra, E. A. G., \&Parellada, C. I. (2003). Entendendo melhor a infecção pelo papilomavirus humano. Manual Schering.

Qual é a relação entre HPV e câncer? (2018). Recuperado em 14 junho, 2018, de http://www.minutobiomedicina.com.br/postagens/2014/02/10/qual-e-a-relacao-entre-hpv-ecancer/

Rama, C. H. (2006). Idade e prevalência da infecção genital por papiloma vírus humano de alto risco em mulheres submetidas a rastreamento para o câncer cervical. Dissertação Mestrado, Faculdade de Saúde Pública, Universidade de São Paulo, São Paulo.

Sacramento, N. A. P. (2011). A importância da estratégia de saúde da família para melhoria de cobertura do exame preventivo do câncer de colo de útero. Trabalho de Conclusão de Curso, Faculdade de Medicina da Universidade Federal de Minas Gerais, Conselheiro Lafaiete, Minas Gerais.

Santos, J. C., Cezar, M. R. S., Lisboa, M. R., \& Moura, M. M. F. (2013). Ocorrência de papilomavírus humano na cérvice uterina de mulheres da região ocidental da Amazônia Brasileira, Acta Amazônia, 43(2), 185-190.

Sedicias, S. (2018). Sintomas e Tratamento do HPV na boca. Recuperado em 19 maio, 2018, de https://www.tuasaude.com/hpv-na-boca/

Silva, H. A, Silveira, L. M. S, França, G. S.,\& Rego, A.C.S.S. (2007).A citopatologia uretral como ferramenta na detecção de efeito citopático do Papiloma vírus Humano (HPV) em pacientes com peniscopia característica de infecção viral. Revista Brasileira de Análises Clínicas, 40(1), 69-71.

Silveira, C. F., Melo, M. M., Rodrigues, L. R., \& Parreira, B. D. M. (2011). Conhecimentos de Mulheres de 40 a 60 anos sobre o Papilloma vírus Humano. Revista Rene, 12(2), $309-315$.

Tacla, M. (2008). HVP - Papiloma vírus Humano. Recuperado em 23 maio, 2018, de http://drauziovarella.ig.com.br/entrevista/hpv.asp. 
Termini, L. (2018). HPV e Câncer de Cabeça e Pescoço. Recuperado em 24 maio, 2018, de http://www.drrobertoelias.com.br/tratamentos/hpv-e-cancer-cabeca-pescoco

Varela, M. L. M. (2009). Colposcopia e Papilomavírus humano (HPV). São Paulo: Manoel Varela.

Zhang, Z. Y., Sdek. P., Cao, J., \& Chen, W. T. (2004). Human papillomavirus type 16 and 18 DNA in oral squamous cell carcinoma and normal mucosa. International Journal of Oral and Maxillofacial Surgery,33(1), 71-4 